\title{
p21-activated kinase 1 (PAK1) expression correlates with prognosis in solid tumors: A systematic review and meta- analysis
}

\author{
Fang Fang ${ }^{1}$, Jian Pan ${ }^{1}$, Yi-Ping $\mathrm{Li}^{1}{ }^{1}$, Gang Li ${ }^{1}$, Li-Xiao Xu${ }^{1}$, Guang-Hao Su ${ }^{1}$, Zhi-Heng \\ $\mathbf{L i}^{1}$, Xing Feng ${ }^{1}$, Jian Wang ${ }^{1}$ \\ ${ }^{1}$ Institute of Pediatric Research, Children's Hospital of Soochow University, Suzhou 215025, Jiangsu, China \\ Correspondence to: Jian Wang, e-mail:wj196312@vip.163.com \\ Xing Feng, e-mail: xing_feng66@hotmail.com
}

Keywords: PAK1, solid tumor, prognosis, survival, meta-analysis

Received: November 25, $2015 \quad$ Accepted: March 14, 2016

Published: March 24, 2016

\section{ABSTRACT}

p21 protein (Cdc42/Rac)-activated kinase 1 (PAK1) expression appears to be predictive of prognosis in various solid tumors, though the evidence is not yet conclusive. We therefore performed a meta-analysis to explore the relationship between PAK1 and prognosis in patients with solid tumors. Relevant publications were searched in several widely used databases, and 15 studies ( 3068 patients) were included in the meta-analysis. Pooled hazard ratios (HRs) and $95 \%$ confidence intervals (CIs) were calculated to evaluate the strength of the association between PAK1 and prognosis. Associations between PAK1 expression and prognosis were observed for overall survival $(\mathrm{HR}=\mathbf{2 . 8 1}, 95 \% \mathrm{CI}=1.07-7.39)$ and disease-specific survival $(H R=2.15,95 \% C I=1.47-3.16)$. No such association was detected for time to tumor progression $(H R=1.78,95 \% C I=0.99-3.21)$. Our meta-analysis thus indicates that PAK1 expression may be a predictive marker of overall survival and disease-specific survival in patients with solid tumors.

\section{INTRODUCTION}

p21 protein (Cdc42/Rac)-activated kinase 1 (PAK1) is a member of the PAK family of proteins, which are effectors of small Rho GTPases (Cdc42 and Rac1) [1, 2]. PAK1 is involved in a variety of cellular functions, including cell motility, survival, mitosis, cytoskeletal rearrangement and angiogenesis [3]. In addition, PAK1 plays key roles in nuclear signaling and activation of the JNK/SAPK and p38MAPK pathways [4, 5]. Although it has been suggested that PAK1 influences the prognosis of various cancer types [3, 6-21], current knowledge of the contribution of PAK1 to cancer prognosis remains limited.

In the present study, we used a statistical approach to systematically investigate the association between PAK1 and the prognosis of solid tumors. Over the past decade, a series of studies have focused on the relationship between PAK1 expression and solid cancer prognosis [3, 6-21], but the results of those individual studies were not conclusive. We therefore performed a meta-analysis using a relatively large sample from 15 studies (3068 patients) with the aim of conclusively determining the relationship between PAK1 and prognosis in patients with solid tumors.

\section{RESULTS}

Studies and data included in this meta-analysis

Through searching and selection, a final list of 17 studies [3, 6-21] was collected for qualitative synthesis (Figure 1). The participants in the studies spanned different ethnicities (11 studies of Asians and 6 studies of Caucasians) and cancer types ( 3 studies of breast cancer, 2 colorectal cancer, 2 gastric cancer, 2 head and neck cancer, 2 ovarian cancer, 1 gastroesophageal junction adenocarcinoma, 1 glioblastoma, 1 hepatocellular carcinoma, 1 pancreatic cancer, 1 renal cell carcinoma, and 1 urothelial carcinoma of the upper urinary tract). Detailed information on these studies is summarized in Table 1. The studies from Aoki et al. and Zhu et al. investigated the 
prognostic utility of p-PAK1 only, and were not included in the quantitative synthesis (meta-analysis). Of the remaining 15 studies, 5 focused on overall survival (OS), 2 focused on disease-specific survival (DSS), 2 focused on disease-free survival (DFS), 1 focused on progressionfree survival (PFS), 1 focused on recurrence-free survival (RFS), and the remaining 4 investigated more than one type of outcome endpoints. In total, the 15 studies eligible for meta-analysis provided a sample of 3068 patients with which to assess the relationship between PAK1 expression and solid tumor prognosis.

\section{Meta-analysis}

In the meta-analysis, three outcome endpoints including DFS, PFS, and RFS that were similar in meaning were combined to use a unified prognostic parameter, time to tumor progression (TTP) instead. The meta-analysis of PAK1 expression was therefore based on three outcome endpoints: OS, DSS and TTP. Eight studies were included in the meta-analysis of OS. A random effects model was used to calculate the pooled hazard ratio (HR) and $95 \%$ confidence interval
(CI) because the heterogeneity test reported a $P$ value of less than 0.01. No significant association was observed between PAK1 expression and OS (pooled HR = 2.08, 95\% CI = 0.93-4.64) (Supplementary Figure S1). Because some individual HRs were indirectly estimated (see Materials and Methods) and were therefore less reliable, we also performed a meta-analysis of OS using only the individual HRs extracted directly from the original articles. Six studies were included in that analysis, and again the heterogeneity test reported a $P$ value of less than 0.01 . We therefore used a random effects model to calculate the pooled $\mathrm{HR}$ and $95 \% \mathrm{CI}$. In this analysis, a significant relationship between PAK1 expression and OS among patients with solid tumors was detected (pooled $\mathrm{HR}=2.81,95 \% \mathrm{CI}=1.07-7.39$ ) (Figure 2A). Four studies were included in the meta-analysis of DSS. A fixed effects model was used to calculate the pooled HR and 95\% CI because the heterogeneity test reported a $P$ value of 0.570 . The result provided evidence of an association between PAK 1 expression and DSS (pooled HR $=2.15,95 \%$ CI $=1.47-3.16$ ) (Figure 2B). Seven studies were used in the meta-analysis for TTP. The heterogeneity test reported a $P$ value of less than 0.01 , so a random effects model
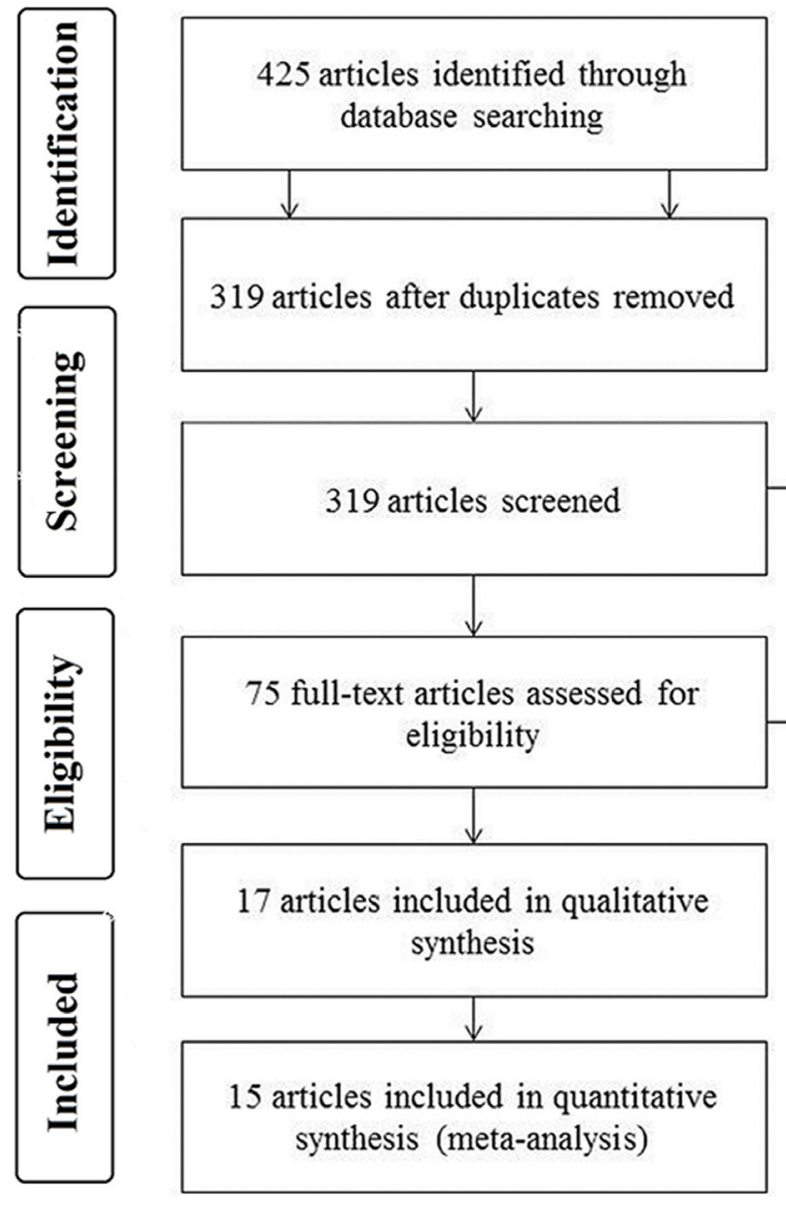

244 articles excluded through title/abstract screening: review $(\mathrm{n}=20)$

not about solid tumor $(\mathrm{n}=4)$

non-clinical study $(\mathrm{n}=220)$

58 articles excluded through full-text screening:

not about PAK1 $(\mathrm{n}=37)$

without survival data $(n=11)$

without sufficient and clear data $(\mathrm{n}=8)$

with overlapped data $(n=2)$

Figure 1: Flow chart of the study selection. 
Table 1: Studies and data included in this meta-analysis

\begin{tabular}{|c|c|c|c|c|c|c|c|c|c|c|c|}
\hline Author & Year & $\begin{array}{l}\text { Patients' } \\
\text { country } \\
\text { of origin }\end{array}$ & Cancer type & $\begin{array}{c}\text { No. of } \\
\text { patients }\end{array}$ & $\begin{array}{l}\text { Stage/ } \\
\text { Grade }\end{array}$ & $\begin{array}{l}\text { Detection } \\
\text { method }\end{array}$ & $\begin{array}{l}\text { Percentage } \\
\text { of high PAK1 } \\
\text { expression, } \\
\text { cutoff value }\end{array}$ & $\begin{array}{l}\text { Median } \\
\text { follow- } \\
\text { up } \\
\text { months }\end{array}$ & Outcome & Outcome definition & $\begin{array}{l}\text { Survival } \\
\text { analysis } \\
\text { method }\end{array}$ \\
\hline Holm & 2006 & Sweden & Breast cancer & 284 & $\begin{array}{c}\text { Grade } \\
\text { I-III }\end{array}$ & $\mathrm{IHC}$ & NA, groups3-5 & 166.8 & RFS & $\begin{array}{l}\text { surgery } \sim \text { recurrence/ } \\
\text { breast cancer death }\end{array}$ & M \\
\hline Aoki $^{\mathrm{a}}$ & 2007 & USA & Glioblastoma & 136 & $\begin{array}{c}\text { Grade } \\
4\end{array}$ & $\mathrm{IHC}$ & NA, NA & 13.5 & OS & surgery $\sim$ NA & M \\
\hline Davidson & 2008 & Norway & $\begin{array}{l}\text { Ovarian } \\
\text { carcinoma }\end{array}$ & 83 & I-IV & $\mathrm{IHC}$ & $\begin{array}{l}57 / 83(68.7 \%), \\
>25 \% \text { of cells }\end{array}$ & NA & PFS,OS & $\begin{array}{l}\text { diagnosis } \sim \text { recurrence, } \\
\text { diagnosis } \sim \text { death/last } \\
\text { follow-up }\end{array}$ & KM \\
\hline Liu & 2009 & China & Gastric cancer & 40 & I-IV & $\begin{array}{l}\text { Western } \\
\text { blotting }\end{array}$ & $\begin{array}{l}20 / 40(50.0 \%), \\
>1.43 \text {-fold }\end{array}$ & NA & DSS & NA & KM \\
\hline Bostner & 2010 & Sweden & Breast cancer & 786 & NA & $\mathrm{IHC}$ & $\begin{array}{l}453 / 786 \\
(57.6 \%), \\
\text { moderate and } \\
\text { strong staining }\end{array}$ & 213.6 & RFS,DSS & $\begin{array}{l}\text { diagnosis } \sim \\
\text { locoregional } \\
\text { recurrence/distant } \\
\text { metastasis, diagnosis } \\
\sim \text { breast cancer death }\end{array}$ & M \\
\hline Kamai & 2010 & Japan & UC-UUT & 108 & $\begin{array}{c}\text { Grade } \\
1-3\end{array}$ & $\begin{array}{l}\text { Western } \\
\text { blotting }\end{array}$ & $\begin{array}{l}49 / 108(45.4 \%), \\
>2.68\end{array}$ & 41.0 & OS,DFS & NA,NA & M \\
\hline $\mathrm{Li}$ & 2010 & China & Colorectal cancer & 73 & A-D & $\mathrm{IHC}$ & $\begin{array}{l}32 / 73(43.8 \%), \\
>1.27\end{array}$ & NA & DSS & NA & KM \\
\hline Siu & 2010 & China & Ovarian cancer & 76 & I-IV & $\mathrm{IHC}$ & $\begin{array}{l}30 / 76(39.5 \%), \\
\text { NA }\end{array}$ & 48.0 & DFS & NA & M \\
\hline Thariat & 2012 & France & $\begin{array}{l}\text { Head and neck } \\
\text { cancer }\end{array}$ & 69 & I-IV & $\begin{array}{l}\text { Western } \\
\text { blotting }\end{array}$ & $\mathrm{NA},>0.47$ & 38.0 & DFS & $\begin{array}{l}\text { diagnosis } \sim \text { first } \\
\text { relapse }\end{array}$ & M \\
\hline $\mathrm{Xu}$ & 2012 & China & $\begin{array}{l}\text { Hepatocellular } \\
\text { carcinoma }\end{array}$ & 52 & I-IV & $\mathrm{IHC}$ & $\begin{array}{l}21 / 52(40.4 \%), \\
\text { NA }\end{array}$ & NA & OS & $\begin{array}{l}\mathrm{NA} \sim \text { death/last } \\
\text { follow-up }\end{array}$ & M \\
\hline $\mathrm{Li}$ & 2013 & China & $\begin{array}{l}\text { Gastroesophageal } \\
\text { junction } \\
\text { adenocarcinoma }\end{array}$ & 113 & II-III & $\mathrm{IHC}$ & $\begin{array}{l}82 / 113(72.6 \%), \\
\text { score }>6\end{array}$ & NA & OS & surgery $\sim$ NA & M \\
\hline Han & 2014 & China & Pancreatic cancer & 72 & I-IV & IHC & $\begin{array}{l}38 / 72(52.8 \%), \\
\text { score }>=4\end{array}$ & NA & OS & $\begin{array}{l}\text { diagnosis } \sim \text { death } / \text { last } \\
\text { follow up }\end{array}$ & M \\
\hline Qian & 2014 & China & Gastric cancer & 131 & I-IV & $\begin{array}{l}\text { Agilent } \\
244 \mathrm{~K} \\
\text { array CGH } \\
\text { platform }\end{array}$ & $\begin{array}{l}6 / 131(4.6 \%), \\
(\log \text { Ratio }>=0.8 \\
\& \\
\text { frequency }>=5 \%) \\
\text { or } \\
(\operatorname{logRatio}>2 \& \\
\text { frequency }>=2 \%)\end{array}$ & NA & OS & NA & NA \\
\hline Ong & 2015 & $\begin{array}{l}\text { UK and } \\
\text { Canada }\end{array}$ & Breast cancer & 980 & $\begin{array}{c}\text { Grade } \\
\text { I-III }\end{array}$ & $\begin{array}{l}\text { Affymetrix } \\
\text { SNP6.0 } \\
\text { array }\end{array}$ & NA, $>5$ copies & 150.0 & OS & diagnosis $\sim$ NA & M \\
\hline Park & 2015 & $\begin{array}{l}\text { South } \\
\text { Korea }\end{array}$ & $\begin{array}{l}\text { Head and neck } \\
\text { cancer }\end{array}$ & 119 & I-IV & $\mathrm{IHC}$ & $\begin{array}{l}50 / 119(42.0 \%), \\
\text { score }>=3\end{array}$ & NA & OS,DSS & NA,NA & $\mathrm{KM}$ \\
\hline Song & 2015 & China & Colorectal cancer & 82 & III-IV & $\mathrm{IHC}$ & $\begin{array}{l}62 / 82(75.6 \%), \\
\text { score }>3\end{array}$ & NA & PFS & NA & KM \\
\hline $\mathrm{Zhu}^{\mathrm{b}}$ & 2015 & China & $\begin{array}{l}\text { Renal cell } \\
\text { carcinoma }\end{array}$ & 119 & I-IV & $\mathrm{IHC}$ & NA, NA & NA & OS & $\begin{array}{l}\text { surgery } \sim \text { death/last } \\
\text { follow-up }\end{array}$ & M \\
\hline
\end{tabular}

${ }^{a}$ Study investigated the prognostic effect of p-PAK1 only and was excluded from quantitative analysis.

${ }^{\mathrm{b}}$ Study investigated the prognostic effect of p-PAK1 only and was excluded from quantitative analysis.

Abbreviations; UC-UUT, urothelial carcinoma of the upper urinary tract; NA, not available; IHC, immunohistochemistry; RFS, recurrence-free survival; OS, overall survival; PFS, progression-free survival; DSS, disease-specific survival; DFS, disease-free survival; M, multivariate cox proportional hazard regression; KM, Kaplan-Meier method. 
was used to calculate the pooled HR and 95\% CI. No significant association between PAK1 expression and TTP was detected (pooled HR $=1.78,95 \%$ CI $=0.99$ 3.21) (Figure 3). The results of our meta-analysis thus suggest that PAK1 expression may be a predictive marker of OS and DSS in patients with solid tumors, but it is not predictive of TTP.

\section{Publication bias test results}

The Begg's funnel plot (Figure 4) and Egger's test showed there was no publication bias for DSS $(P=0.901)$ or for TTP $(P=0.062)$. However, publication bias may exist for $\operatorname{OS}(P=0.032)$ in the analysis of high versus low PAK1 expression.
$\mathbf{A}_{\text {stud }}$

ID

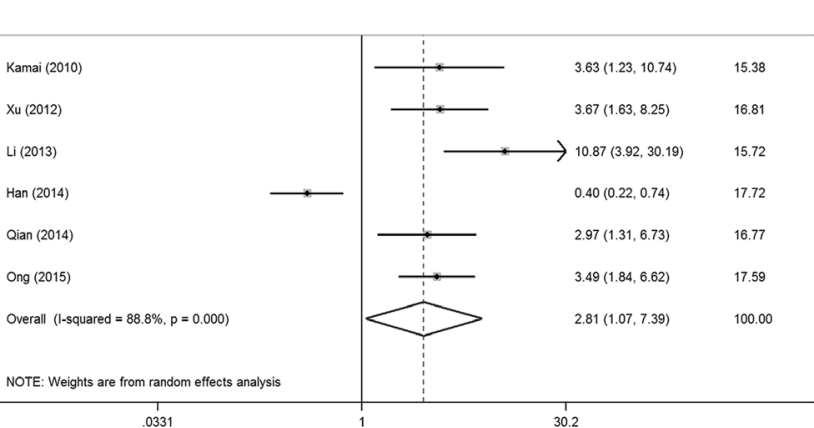

B Study

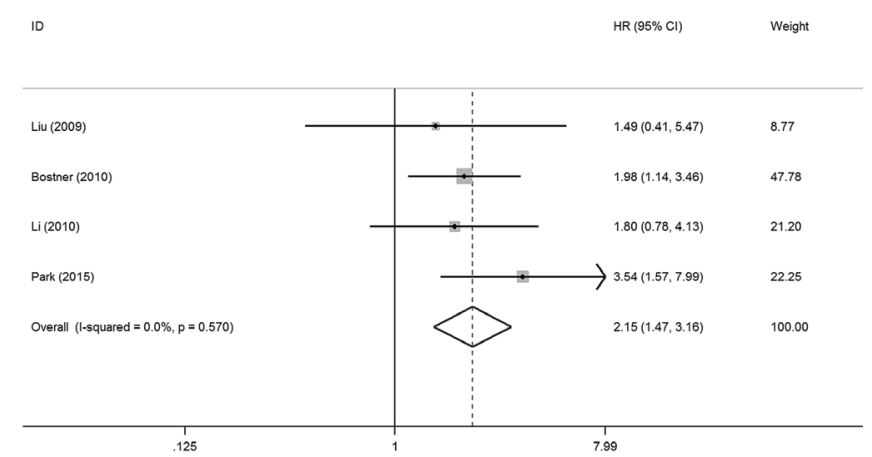

Figure 2: Forest plots of the meta-analysis of the association between PAK1 expression and the prognosis of patients with solid tumors. A. Overall survival (using only individual HRs extracted directly from the original articles) B. Disease-specific survival. Abbreviations: HR, hazard ratio; CI, confidence interval.

Study

ID

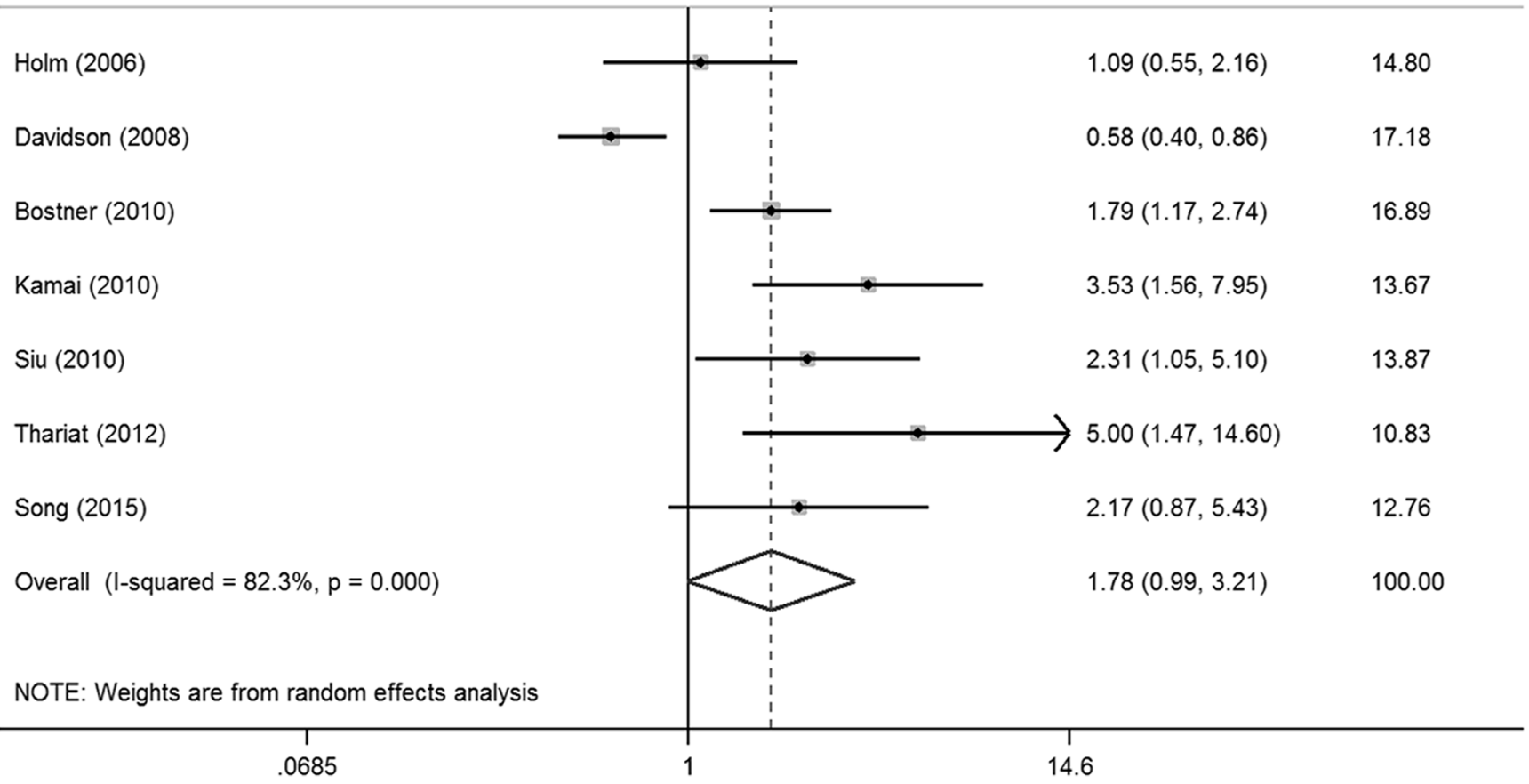

Figure 3: Forest plot of the meta-analysis of the association between PAK1 expression and solid tumor progression. Abbreviations: HR: hazard ratio; CI: confidence interval. 

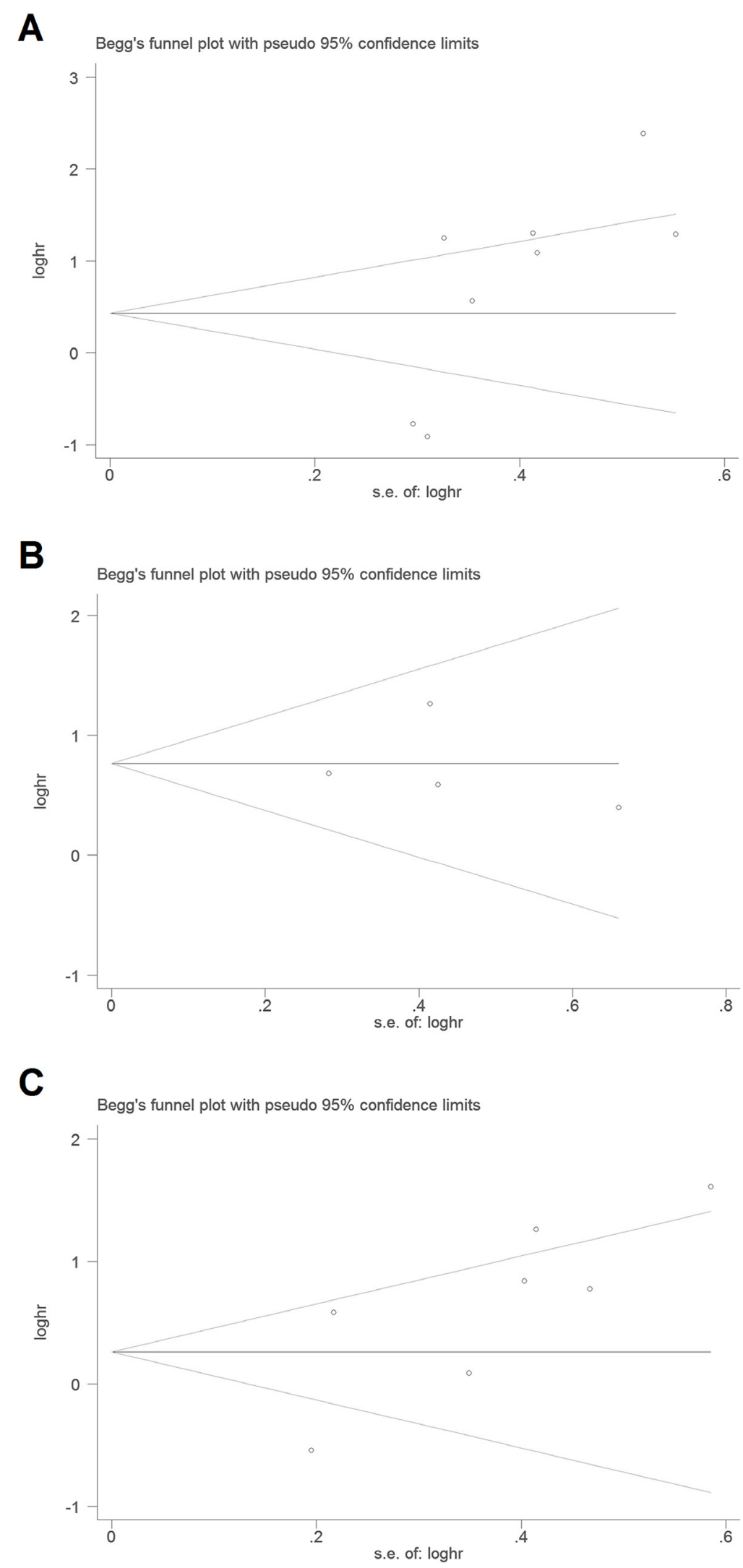

Figure 4: Begg's funnel plots for the studies involved in the meta-analysis of PAK1 expression and the prognosis of patients with solid tumors. A. Overall survival. B. Disease-specific survival. C. Time to tumor progression. Abbreviations: loghr, logarithm of hazard ratios; s.e., standard error. 


\section{DISCUSSION}

The results of our meta-analysis suggest that higher tumoral PAK1 expression is associated with an unfavorable prognosis and is predictive factor associated with OS and DSS in patients with solid tumors. PAK1 is an effector of small Rho GTPases (Cdc42 and Rac1) [2]. PAK1 and Rac1 reportedly play important roles within cancer cell signaling networks and contribute to invasive and metastatic phenotypes [22, 23]. On the other hand, our meta-analysis indicates that PAK1 expression is not significantly associated with TTP in patients with solid tumors. The heterogeneity across the included studies is one potential reason for this. In addition, the combined effects of PAK1 with other molecular and environmental factors likely differ among cancer types.

Our meta-analysis has several limitations, so the results should be considered with a degree of caution. One limitation is that the sample size was not sufficient, particularly for the analysis of DSS. A second limitation is the heterogeneity caused by the diverse methods used to detect PAK1 expression and the varied cutoff values used in individual studies. The third limitation is that the patient data were not adjusted to account for details of the patients' characteristics, such as age and lifestyle. In addition, subgroup meta-analysis based on cancer type, PAK1 nuclear localization and p-PAK1 expression could not be carried out with the existing data. To achieve a more convincing conclusion, further analysis using a larger sample size, a unified detection method and adjusted individual data will be required, along with a stratified analysis based on cancer type, PAK1 nuclear localization and p-PAK1 expression.

\section{MATERIALS AND METHODS}

\section{Literature search, selection and data collection}

For this study, we searched for papers published before May 6, 2015 using the keywords "p21 protein (Cdc42/Rac)-activated kinase 1" / "PAK1" / "PAKalpha", "cancer" / "tumor" / "neoplasm" / "carcinoma", and "survival" / "prognosis" / "mortality" / "death" independently in PubMed and Web of Science. Among the papers identified, were further selected for the metaanalysis using the following selection criteria. 1) The full text of the study was in English. 2) The study provided adequate data for individual HRs and $95 \%$ CIs to be extracted or calculated [24]. 3) When studies sharing the same patient sample were compared, the most complete study among them was included in our meta-analysis.

Three investigators independently collected data from each eligible paper. The data collected included the name of first author, publication year, patients' country of origin, cancer type, number of patients, cancer stage or grade, detection method, percentage exhibiting high PAK1 expression and the corresponding cutoff value, median follow-up months, outcome endpoints, outcome definition, survival analysis method, and the HR and 95\% $\mathrm{CI}$ for the high PAK1 expression group versus low PAK1 expression group. Individual HRs and 95\% CIs were estimated [24] if only Kaplan-Meier survival plots were available. Multivariate HRs and 95\% CIs were selected if both univariate and multivariate results were reported in an individual study. By checking among the three investigators, the final data collected was determined.

\section{Meta-analysis methods}

Using the data collected from each eligible paper, we performed a meta-analysis of the outcomes to evaluate the relationship between PAK1 and solid cancer prognosis. Stata version 14.0 (Stata Corporation, College Station, TX, USA) was used to carry out the statistical analysis. Because the outcome endpoints DFS, PFS and RFS are similar in meaning, they were combined and a unified prognostic parameter, TTP, was used for the metaanalysis. Pooled HRs and 95\% CIs for three outcome endpoints (OS, DSS, and TTP) were calculated. All the pooled HRs and $95 \%$ CIs were calculated using a fixed effects or random effects model. The model was chosen using a heterogeneity test. For the heterogeneity test, we performed the $\chi^{2}$-based $Q$-test [25]. When the $Q$-test reported a $P$ value of more than 0.10 , a fixed effects model was used to calculate the pooled HRs [26], otherwise random effects model was used [27].

Publication bias was tested using Begg's funnel plot and the Egger's test [28]. If the funnel plot was asymmetric and the Egger's test reported a $P$ value of less than 0.05 , publication bias was deemed to probably exist.

\section{CONFLICTS OF INTEREST}

The authors declare that there is no conflicts of interest.

\section{GRANT SUPPORT}

This work was supported by grants from National Natural Science Foundation (grant number 81501840 for Fang F, 81271378 and 81471488 for Feng X, 81570125 for Pan J, 81501700 for Li YP, 31400738 for Li G, 81502157 for Xu LX), Major International (Regional) Joint Research Project (grant number 81420108022 for Wang J), Key Laboratory of Suzhou (grant number SZS201307 for Wang J), Natural Science Foundation of Jiangsu Province (grant number BK20130266 for Su GH), and Suzhou science and technology development project (grant number SYSD2014102 for Fang F). 


\section{REFERENCES}

1. Dummler B, Ohshiro K, Kumar R, Field J. Pak protein kinases and their role in cancer. Cancer Metastasis Rev. 2009; 28:51-63.

2. Narumiya S, Ishizaki T, Watanabe N. Rho effectors and reorganization of actin cytoskeleton. FEBS Lett. 1997; 410:68-72.

3. Han J, Wang F, Yuan SQ, Guo Y, Zeng ZL, Li LR, Yang J, Wang DS, Liu MY, Zhao H, Liu KY, Liao JW, Zou $\mathrm{QF}$, et al. Reduced expression of $\mathrm{p} 21$-activated protein kinase 1 correlates with poor histological differentiation in pancreatic cancer. BMC Cancer. 2014; 14:650.

4. Zhang S, Han J, Sells MA, Chernoff J, Knaus UG, Ulevitch RJ, Bokoch GM. Rho family GTPases regulate p38 mitogen-activated protein kinase through the downstream mediator Pak1. J Biol Chem. 1995; 270:23934-23936.

5. Frost JA, Xu S, Hutchison MR, Marcus S, Cobb MH. Actions of Rho family small $\mathrm{G}$ proteins and p21-activated protein kinases on mitogen-activated protein kinase family members. Mol Cell Biol. 1996; 16:3707-3713.

6. Holm C, Rayala S, Jirström K, Stål O, Kumar R, Landberg G. Association between Pak1 expression and subcellular localization and tamoxifen resistance in breast cancer patients. J Natl Cancer Inst. 2006; 98:671-680.

7. Aoki H, Yokoyama T, Fujiwara K, Tari AM, Sawaya R, Suki D, Hess KR, Aldape KD, Kondo S, Kumar R, Kondo Y. Phosphorylated Pak1 level in the cytoplasm correlates with shorter survival time in patients with glioblastoma. Clin Cancer Res. 2007; 13:6603-6609.

8. Davidson B, Shih IeM, Wang TL. Different clinical roles for p21-activated kinase-1 in primary and recurrent ovarian carcinoma. Hum Pathol. 2008; 39:1630-1636.

9. Liu F, Li X, Wang C, Cai X, Du Z, Xu H, Li F. Downregulation of $\mathrm{p} 21$-activated kinase-1 inhibits the growth of gastric cancer cells involving cyclin B1. Int J Cancer. 2009; 125:2511-2519.

10. Bostner J, Skoog L, Fornander T, Nordenskjöld B, Stål O. Estrogen receptor-alpha phosphorylation at serine 305, nuclear p21-activated kinase 1 expression, and response to tamoxifen in postmenopausal breast cancer. Clin Cancer Res. 2010; 16:1624-1633.

11. Kamai T, Shirataki H, Nakanishi K, Furuya N, Kambara T, Abe H, Oyama T, Yoshida K. Increased Rac1 activity and Pak1 overexpression are associated with lymphovascular invasion and lymph node metastasis of upper urinary tract cancer. BMC Cancer. 2010; 10:164.

12. Li LH, Zheng MH, Luo Q, Ye Q, Feng B, Lu AG, Wang ML, Chen XH, Su LP, Liu BY. P21-activated protein kinase 1 induces colorectal cancer metastasis involving ERK activation and phosphorylation of FAK at Ser-910. Int J Oncol. 2010; 37:951-962.
13. Siu MK, Wong ES, Chan HY, Kong DS, Woo NW, Tam KF, Ngan HY, Chan QK, Chan DC, Chan KY, Cheung AN. Differential expression and phosphorylation of Pak1 and Pak2 in ovarian cancer: effects on prognosis and cell invasion. Int J Cancer. 2010; 127:21-31.

14. Thariat J, Bensadoun RJ, Etienne-Grimaldi MC, Grall D, Penault-Llorca F, Dassonville O, Bertucci F, Cayre A, De Raucourt D, Geoffrois L, Finetti P, Giraud P, Racadot S, et al. Contrasted outcomes to gefitinib on tumoral IGF1R expression in head and neck cancer patients receiving postoperative chemoradiation (GORTEC trial 2004-02). Clin Cancer Res. 2012; 18:5123-5133.

15. Xu J, Liu H, Chen L, Wang S, Zhou L, Yun X, Sun L, Wen Y, Gu J. Hepatitis B virus X protein confers resistance of hepatoma cells to anoikis by up-regulating and activating p21-activated kinase 1. Gastroenterology. 2012; 143:199212.e4.

16. Li Z, Zou X, Xie L, Dong H, Chen Y, Liu Q, Wu X, Zhou D, Tan D, Zhang H. Prognostic importance and therapeutic implications of PAK1, a drugable protein kinase, in gastroesophageal junction adenocarcinoma. PLoS One. 2013; 8:e80665.

17. Qian Z, Zhu G, Tang L, Wang M, Zhang L, Fu J, Huang C, Fan S, Sun Y, Lv J, Dong H, Gao B, Su X, et al. Whole genome gene copy number profiling of gastric cancer identifies PAK1 and KRAS gene amplification as therapy targets. Genes Chromosomes Cancer. 2014; 53:883-894.

18. Ong CC, Gierke S, Pitt C, Sagolla M, Cheng CK, Zhou W, Jubb AM, Strickland L, Schmidt M, Duron SG, Campbell DA, Zheng W, Dehdashti S, et al. Small molecule inhibition of group I p21-activated kinases in breast cancer induces apoptosis and potentiates the activity of microtubule stabilizing agents. Breast Cancer Res. 2015; 17:59.

19. Park J, Kim JM, Park JK, Huang S, Kwak SY, Ryu KA, Kong G, Park J, Koo BS. Association of p21-activated kinase-1 activity with aggressive tumor behavior and poor prognosis of head and neck cancer. Head Neck. 2015; 37:953-963.

20. Song B, Wang W, Zheng Y, Yang J, Xu Z. P21-activated kinase 1 and 4 were associated with colorectal cancer metastasis and infiltration. J Surg Res. 2015; 196:130-135.

21. Zhu Y, Liu H, Xu L, An H, Liu W, Liu Y, Lin Z, Xu J. p21-activated kinase 1 determines stem-like phenotype and sunitinib resistance via NF- $\mathrm{kB} / \mathrm{IL}-6$ activation in renal cell carcinoma. Cell Death Dis. 2015; 6:e1637.

22. Sahai E, Marshall CJ. RHO-GTPases and cancer. Nat Rev Cancer. 2002; 2:133-142.

23. Kumar R, Gururaj AE, Barnes CJ. p21-activated kinases in cancer. Nat Rev Cancer. 2006; 6:459-471.

24. Tierney JF, Stewart LA, Ghersi D, Burdett S, Sydes MR. Practical methods for incorporating summary time-to-event data into meta-analysis. Trials. 2007; 8:16. 
25. Lau J, Ioannidis JP, Schmid CH. Quantitative synthesis in systematic reviews. Ann Intern Med. 1997; 127:820-826.

26. Mantel N, Haenszel W. Statistical aspects of the analysis of data from retrospective studies of disease. J Natl Cancer Inst. 1959; 22:719-748.
27. DerSimonian R, Laird N. Meta-analysis in clinical trials. Control Clin Trials. 1986; 7:177-188.

28. Egger M, Davey Smith G, Schneider M, Minder C. Bias in meta-analysis detected by a simple, graphical test. BMJ. 1997; 315:629-634. 